Cecília Mariz - Reflexões sobre a reação afro-brasileira...

\title{
REFLEXÕES SOBRE A REAÇÃO AFRO-BRASILEIRA À GUERRA SANTA
}

\section{Cecilia Loreto Mariz"}

Muito instigante e criativo o texto de Ari Pedro Oro sobre a chamada guerra santa desencadeada pelos neopentecostais contra as religioes afro-brasileiras. A maior originalidade deste texto é estudar a atitude dos membros da religião afro-brasileira em relação a esta guerra. Diferentemente dos demais autores, que até então estudararn o tema, Oro não restringe sua análise aos neopentecostais, aqueles que estão na ofensiva desta guerra. Vai mais além, e se pergunta: por que a reação dos membros da religiões afro-brasileiras aos ataques que vem sofrendo é relativamente débil? Embora reconheça que esses grupos as vezes reagem, e que certas lideranças das religiões afro-brasileiras se incomodam bastante com os ataques que vêm sendo feitos a sua religião, o autor chama a atenção para a pouca freqüência dessas reações e sua debilidade relativa.

Ao tentar explicar a relativa escassez e fraqueza dessas reações o texto de Oro nos oferece pistas não somente para entender o significado sócio-cultural dessa guerra santa, mas tarnbém para entender o que distingue as cosmovisões das igrejas neopentecostais da dos grupos afro-brasileiros. Apesar de estar mais preocupado em sublinhar as similaridades entre essas duas religiões ou os frame alignements, para usar a terminologia que o autor adota emprestada de Snow, que as aproximam e possibilitam o amplo trânsito entre essas duas religiões, a análise elaborada por Ari Pedro Oro nos apresenta de forma implícita distinções importantes entre essas duas visões religiosas de mundo. No presente texto tento explicitar essas diferenças seguindo as pistas que Oro oferece.

Quase toda literatura sobre neopentecostais tem se dedicado a sublinhar as semelhanças entre essas igrejas e as religiões afrobrasileiras. Sem negar essas similaridades evidentes, quero chamar atenção para aspectos importantes onde divergern. O estudo das diferenças entre a cosmovisão pentecostal e a afro-brasileira tem sido

* Professora da Universidade Federal do Rio de Janeiro. Debates do NER, Porto Alegre, ano 1, n. 1, p. 96-103. Novembro de 1997. 
subestimado pela literatura sobre o tema. Argumento que a maneira que cada uma dessas religiões concebe conflitos religiosos e guerras santas é um dos elementos mais importantes que as distingue. $\mathrm{O}$ evidenciar dessas distinções, além de ajudar a entender a diferença entre a agressividade da ofensiva neopentecostal e a relativa indiferença à essa agressão por parte das religiões afro-brasileiras, vai colocar sob outro prisma a expansão e sucesso da Igreja Universal e do neopentecostalismo no Brasil, relacionando-os com a novidade que propõem, e não apenas com a continuidade desses grupos religiosos com as religiões populares de nosso país, como tem feito em geral a literatura sobre o tema.

Os apontados por Oro como responsáveis pela relativa passividade dos afro-brasileiros nessa guerra nos oferece pistas interessantes que acredito possam nos levar a melhor caracterizar qual a principal ruptura proposta pelo neopentecostalismo em relação não somente ao campo religioso afro-brasileiro, mas também ao catolicismo rústico e aos principais elementos de uma cosmovisão que já foi identificada como religiosidade mínima brasileira (Droogers, 1987).

O primeiro argumento apresentado pelo autor para explicar a fraca reação dos membros das religiões afro-brasileiras à guerra neopentecostal se relaciona com a "não institucionalização" dessas religiões, e com o fato da sua organização ser baseada sobre líderes que concorrem e competem entre si. Oro afirma que a desunião é tal que é até difícil encontrar um inimigo em comum. Recolocando a questão sob outra ótica diria que já não há união devido a falta desse inimigo em comum. Nessa religião compartilhar uma mesma fé não significa que se tenha um projeto de mudar o mundo pelo qual se lute. Não há uma causa pela qual se lute, nem há um mal único que se deva combater. Ao contrário da cosmovisão cristã, as religiões afro-brasileiras não possuem uma proposta ética universal. Não apresenta uma proposta de mudar nem o mundo nem o indivíduo. Esta religiosidade não pretende ser missionária. Através dessas religiões os indivíduos buscam satisfazer o seu "santo" para ter sucesso no mundo sem mudá-lo, mas se adaptando a ele.

No entanto, isso não significa que não haja idéia de combate ou luta nessas religiões. Há lutas sim, mas trata-se de competições

Debates do NER, Porto Alegre, ano 1, n. 1, p. 96-103. Novembro de 1997. 
entre líderes religiosos. Urn líder procura desqualificar a competência, o conhecimento da tradição, e o poder dos rituais dos outros. A competição interna não é privilégio do campo afrobrasileiro. Todos sabem quantas divergências e concorrências também ocorrem no campo cristão e em especial evangélico e neopentecostal.

A desunião do campo religioso afro-brasileiro, contudo, é bem distinta daquela das denominações evangélicas e do campo cristão em geral. Argumento aqui que esta distinção não se explica apenas pela falta de institucionalização das religiões afro-brasileiras. A principal diferença reside na maneira como cada uma dessas visões conhece e define o que seja o mal. Esses diferentes conceitos e definições implicam, por sua vez, na presença ou ausência de urn sistema ético universal religiosamente justificado ${ }^{1}$. Com esta ruptura fundamental nos pressupostos cognitivos sobre o mal, os neopentecostais apesar de todos seus rituais "mágicos" de exorcismo propõem urn papel ético para à religião. A ruptura passa a ser essa nova função da religião que deve agora defender uma ética universal.

Sendo o mal concebido de forma transcendental, a luta ética contra ele é uma luta religiosa. As religiões afro-brasileiras não se preocupam em defender ou combater o mal porque, ao contrário do cristianismo, não concebem o demônio ou nenhuma fonte única de mal, transcendente e absoluta, responsável por todos os pecados e sofrimentos da humanidade. Nessas religiões, o mal em geral tem origem nos seres humanos. Quando algum infortúnio acontece busca-se identificar quem o desejou e planejou e quem recorreu a um orixá, ou outra força sobrenatural, para que fizesse aquele malefício. Assim, os seres espirituais não são os responsáveis pelo mal. Dependendo do "trabalho" feito, eles podem agir para o bem e/ou para o mal. Os inimigos, contra quem se luta, são outros seres humanos que desejam, às vezes apenas ocasionalmente, nosso mal. Como não se pressupõe nesta visão o bem e o mal como totalmente exclusivos também não se aceita o embate entre o bem e o mal. $\mathrm{O}$ conflito ocorre entre pessoas, que podem ser boas ou más,

1 É importante deixar claro que não se argumenta que os membros das religiões afro-brasileiras não possuam sistemas éticos universais, mas apenas que esses não são justificados nem propostos por suas práticas ou mitos religiosos.

Debates do NER, Porto Alegre, ano 1, n. 1, p. 96-103. Novembro de 1997. 
dependendo do momento. Os espíritos são meros instrumentos usados por essas pessoas. Embora tenham mais poder do que as pessoas, os espíritos não tem superioridade moral nem no bem nem no mal. Os espíritos nem são mais santos do que os homens nem tão maléficos. Daí não faz sentido nesta visão a idéia de guerra santa ou guerra espiritual. Entendem-se os conflitos religiosos não como conflitos entre espíritos que defendem princípios e virtudes opostas. Os conflitos são vistos como fruto da natural oposição de interesses entre seres humanos na competição por bens escassos. Não há defesa da superioridade moral de urn interesse sobre outro. Também não se pressupõe a vitória final de um grupo mais justo sobre um menos justo. Não é por ser justo ou virtuoso que um lado terá vitória na concepção das religiões afro-brasileiras, mas pela eficácia de seus rituais, de seus "trabalhos" e seu compromisso com orixás poderosos. Não há uma luta entre religiões verdadeiras, princípios morais últimos, mas sim uma luta entre práticas eficientes. A luta religiosa nesse campo é em geral uma competição entre líderes que tentam mostrar maior poder.

A acusação de que alguém usou seus conhecimentos religiosos e os poderes dos orixás para fazer o mal é comum entre os membros das religiões afro-brasileiras. Os membros das religiões afro-brasileiras tem temor desse uso maléfico e alimentam esse temor em outros de dentro e de fora de seu campo religioso. Sobre esse temor se baseiam o prestígio e o poder dessas práticas, mais respeitadas pelo poder que dizem possuir ou pelo medo que inspiram do que por sua possível virtude moral. Como bem lembra Oro e os diversos autores que cita, essa crença é aceita sem questionamento nas igrejas pentecostais e neopentecostais que incorporam esses mesmos pressupostos cognitivos sobre os poderes rituais das religiões que combatem. Acreditar que se faz o mal nas religiões afro-brasileiras é uma "verdade" interna a essas religiões. Em conseqüência, seus membros não podem negar essas acusações, mesmo quando elas partem das igrejas neopentecostais, porque eles próprios delas se utilizam também. Acreditam que podem fazer o mal, que podem negociar com os espíritos para conseguir vantagens materiais ou outras, e esta crença também é útil como chamariz para novos adeptos ou ao menos para assustar inimigos. Já na visão

Debates do NER, Porto Alegre, ano 1, n. 1, p. 96-103. Novembro de 1997. 
neopentecostal e no cristianismo em geral, o ser humano quando age de maneira má esta sendo escravizado pelo demônio. O demônio e o responsável por todo o mal. Por isso ele deve ser combatido. Também por isso qualquer religião que negocie com o mal é demoníaca e deve ser da mesma forma combatida.

É verdade também que os membros das religiões afrobrasileiras reconhecem, e por isso veneram a Santíssima Trindade, Jesus, o Espirito Santo, Deus Pai, como entidades divinas e superiores em poder e virtude aos homens e a outros espíritos. Oro lembra disso e observa que "os membros das religiões afrobrasileiras aceitam e reconhecem o caráter divino do Espírito Santo e da Santíssima Trindade. Assim não podem lutar contra os neopentecostais usando as suas próprias armas". Para complementar a constatação do autor, acrescento ainda que na verdade são os neopentecostais quem usam as armas próprias do campo afro-brasileiro para atacá-los. Além disso, por outro lado, o uso desta arma efetivamente atribuí um poder sobrenatural às religiões assim acusadas. Nisso o neopentecostalismo se afasta das versões mais racionalizadas e menos encantadas do cristianismo contemporâneo, que predominam nas igrejas históricas e na elite intelectual católica e no seu clero. Essas versões descreditam os poderes sobrenaturais das religiões afro-brasileiras. Nessa descrença reside uma tolerância quase paternalista que adotam em relação àquelas religiões. A ruptura do neopentecostalismo (e também do pentecostalismo em geral) em relação as visões do cristianismo mais intelectualizado, que predominam nas elites dessas outras igrejas, é basicamente cognitiva, como já observei em outros trabalhos (Mariz, 1992; 1995). De fato o cristianismo pentecostal conhece o mundo diferentemente das versões não pentecostais e mais racionais. Distingue-se por não definir as religiões afro-brasileiras como meras superstições, e ainda por considerar possessão um sintoma de histeria ou sugestão como fazem as versões mais intelectualizadas do cristianismo. Diferem ainda quando pregam os milagres cotidianos. Mas isso não significa que o neopentecostalismo, por compartilhar pressupostos cognitivos com as religiões afro-brasileiras, não possa ser nem definido como cristão nem como evangélico como querem alguns. Também não quer dizer que o neopentecostalismo não

Debates do NER, Porto Alegre, ano 1, n. 1, p. 96-103. Novembro de 1997. 
proponha de fato uma ruptura radical em relação as religiões afrobrasileiras. Essa ruptura se reflete também no fato de que no neopentecostalismo a ocorrência de um prodígio não é suficiente para tornar um ser espiritual digno de culto. Também a simples demonstração de poder espiritual por líderes religiosos passa a ser menos importante como critério de conversão. Após a conversão passa-se a distinguir os milagres de Deus daquele do diabo.

Outro fator que explicaria, segundo Oro, a ausência de qualquer ação de revide aos ataques que vem sofrendo, e a reação defensiva fraca por parte das religiões afro-brasileiras, seria o pouco prestígio social dessas religiões e sua falta de poder político. Afirma o autor que essas religiões "possuem um passado feito de estigmatizações, preconceitos, e até repressões, religiosas $e$ policiais. Ora este passado não foi apagado da memória coletiva dos adeptos dessa religiões; até certo ponto ele se mantêm até hoje $e$, por certo, contribui para a formação do atual ethos dos seus membros". Sugere assim que essas religiões, por já serem muito perseguidas, e além do mais por não terem nenhum suporte exterior de instâncias políticas e sociais fora de seus quadros religiosos, desenvolveram a passividade e o sincretismo como estratégias de resistência. No entanto, lembro que o cristianismo em sua origem foi uma religião bastante perseguida; também as denominações evangélicas sempre foram perseguidas em outros momentos históricos. Destaco ainda que a própria Igreja Universal, que representa melhor este espírito bélico pentecostal, sofre por sua vez preconceitos e também foi perseguida. Em todos esses casos citados as estratégias desenvolvidas para sobreviver à essas perseguições não foram a indiferença ou inércia em relação as acusações. Cada vez que atacada a Igreja Universal busca ampliar seu poder político. Da mesma forma agiu o cristianismo desde os seus primórdios. Por isso neste aspecto, tendo a discordar de Oro e sugiro que a aparente inércia do povo de santo em relação aos ataques dos neopentecostais se explica mais por sua cosmovisão do que por sua fragilidade política e social.

Muito interessante a conclusão de Ari P. Oro de que a guerra promovida pelo neopentecostalismo, e em especial a Igreja Universal, paradoxalmente põe em evidência as religiões afro-

Debates do NER, Porto Alegre, ano 1, n. 1, p. 96-103. Novembro de 1997. 
brasileiras e contribui para sua institucionalização e organização. De fato, a religião afro-brasileira deixa de ser acusada pela mídia de charlatanismo e ludibriadora do mais pobre. Agora essa religião é tida como "vítima" e quem tem sido bem mais criticado e acusado pela midia é o neopentecostalismo e em especial a Igreja Universal do Reino de Deus. Essa conclusão de Ari Pedro Oro também está sendo reafirmada pelas observações que Patricia Moreira tem feito na Igreja Universal na Argentina. Em artigo que em breve será publicado, Patricia Moreira e Pablo Semán apontam para o fato de que por causa de seu estilo missionário ser baseado no combate aos espíritos do panteão afro-brasileiro, a Igreja Universal tem contribuído bastante para dar visibilidade e fazer conhecer nas camadas populares de Buenos Aires a religião afro-brasileira e seus orixás. Se, por um lado, como lembra o próprio Oro, as religiões afro-brasileiras precedem na Argentina e no Uruguai a entrada das igrejas neopentecostais, por outro, essas últimas contribuem para a divulgação das primeiras.

$\mathrm{O}$ argumento que venho desenvolvendo em todo este texto é que Ari Pedro Oro, ao chamar atenção e buscar explicações para a relativa indiferença dos membros das religiões afro-brasileiras em relação a guerra santa dos neopentecostais, coloca em evidência o aspecto fundamental que distingue essas duas visões. Como salienta o próprio Oro, o neopentecostalismo, embora possua continuidades com essas religiões, propõe transformar a visão de mundo daquele que delas se originaram. Oro identifica no neopentecostalismo o que Snow chama de frame transformation. Sugiro que esta transformação proposta se assemelha aquela que ocorreu na Idade Moderna quando o saber religioso erudito perseguia a religiosidade popular acusando algumas práticas de magias e alguns líderes de bruxas ou bruxos que teriam feito pacto com o diabo ${ }^{2}$.

2 A reforma da cultura popular na ldade Moderna européia como aponta Peter Burke (1989) teve duas fases. Na primeira perseguiam-se essas práticas como magia negra e bruxaria, os refonnadores faziam uma guerra santa. Na segundo fase, a cultura e religiosidade popular era reduzida a um erro cognitivo e desqualificada como superstição ou uma forma de conhecer inferior.

Debates do NER, Porto Alegre, ano 1, n. 1, p. 96-103. Novembro de 1997. 
Cecília Mariz - Reflexões sobre a reação afro-brasileira...

\section{Referências Bibliográficas}

BURKE, Peter (1989). A Cultura Popular na Idade Moderna. São Paulo, Companhia das Letras.

DROOGERS (1987). A religiosidade mínima brasileira. In: Religião e Sociedade 14/2 (62-86).

MARIZ, Cecília L. (1992). Cebs e Pentecostalismo: novas reformas da religião popular no Brasil. In: Revista Eclesiástica Brasileira 51 (203): 599-611.

( 1995). El debate en torno del pentecostalismo autónomo en Brasil. In: Sociedad y Religion 13 (21-32).

ORO, Ari Pedro (1997). Neopentecostais e afro-brasileiros: quem vencerá esta guerra? Debates do NER, ano 1, n. 1, 1997.

Debates do NER, Porto Alegre, ano 1, n. 1, p. 96-103. Novembro de 1997. 